\title{
PUBLIC SPENDING ON HUMAN CAPITAL FORMATION AND ECONOMIC GROWTH IN PAKISTAN
}

\author{
Syed Ammad Ali, Qazi Masood Ahmed and Lubna Naz*
}

This present paper captures the growth effects of public physical and human capital investment, which highlights the relative efficacy of these types of investments on sectoral and aggregate output, employment and private investment, and indicates which sector of the economy of Pakistan is benefiting the most from these investments. It uses the production function approach based on the Mankiw, Romer and Weil (1992) growth models and applied the Fully Modified Ordinary Least Square (FM-OLS) technique using data from the Pakistan economy during the period 1964-2013. The results show that human capital investment in the public sector has a positive significant effect in all models. The coefficient indicates that a 1 per cent change in human capital investment will increase the output of the manufacturing sector by 0.44 per cent; the output of the services sector by 0.15 per cent; the output of agriculture sector by 0.094 per cent; and the aggregate output by 0.027 per cent. The public physical investment has the highest impact on manufacturing sector output (0.084 per cent) followed by aggregate output (0.034 per cent). The estimated elasticities indicate that at the sectoral level, public human capital investment has a greater output effect than the public physical investment, while at the aggregate level, the public-physicalinvestment effect dominates.

JEL classification: O40, O53, E62, H40.

Keywords: Economic growth, physical capital, human capital, Pakistan.

Syed Ammad Ali, PhD, Research Fellow, Department of Economics University of Karachi (e-mail: ammadsyed@yahoo.com); Qazi Masood Ahmed, PhD, Director, Centre for Business \& Economics Research, Institute of Business Administration, Karachi (e-mail: qmasood@iba.edu.pk), and Lubna Naz, PhD, Assistant Professor, Department of Economics, University of Karachi (e-mail: lubnanaz@uok. edu.pk). We acknowledge the reviewers for their valuable comments and suggestions. 


\section{INTRODUCTION}

The differences in growth among the countries initially mainly considered the availability of physical capital stock. However, after the seminal work of Lucas (1988), Romer (1990) and Mankiw, Romer and Weil (1992), the role of human capital in economic growth has become widely accepted, along with the physical capital stock. Human capital stock is determined through education, health, research and development, and training. However, it is still being debated as to which factor is most efficient and effective with regard to human capital accumulation. Another burning issue pertains to the role of public investment. The effectiveness of public investment on private investment and consequently on growth is widely discussed in economic literature. The classical school of thought is of the view that increments in public spending reduces economic growth by crowding out private investment, as higher spending requires higher taxes at individual and corporate levels, which create a distortion in the choice of economic agents. The Keynesians, on the other hand, consider government spending as a key variable for economic growth. They argue that government development expenditures on health, education, and infrastructure increase labour productivity and reduce the cost of conducting business, which spurs gross private domestic investment.

In Pakistan, the public sector is intended to play an effective and efficient role with regard to economic growth and the welfare of the society. In pursuance of these objectives, the Government is trying to improve infrastructure and energy generation and distribution, and promote the establishment of health and education facilities. However, the data trend, as depicted in figure 1, indicates that the ratio of physical investment, the sum of public investment in electricity and gas distribution, and in the transport, storage and communication sector to GDP, and the ratio of human capital investment, the sum of the development expenditures in the health and education sectors to GDP are falling.

The broad objectives of the present study are to test the relative effects of public physical investment and of public human capital investment on economic growth. The effects of public investment are evaluated in three major sectors of the economy, namely the agriculture, manufacturing, and services sectors. This study used the Fully Modified Ordinary Least Square (FM-OLS) technique to measure the long-term relationship between public physical and human capital and economic growth at aggregate and sectoral levels. FM-OLS has several advantages over the previously applied vector error correction model (VECM), ordinary least square (OLS), and autoregressive distributed lag (ARDL) techniques. This study is among a pool very few undertaken in the developing countries that capture the growth effects of public physical and human capital investment. It highlights, in particular, the size of 
Figure 1. Public physical and human capital investment to GDP ratio in Pakistan

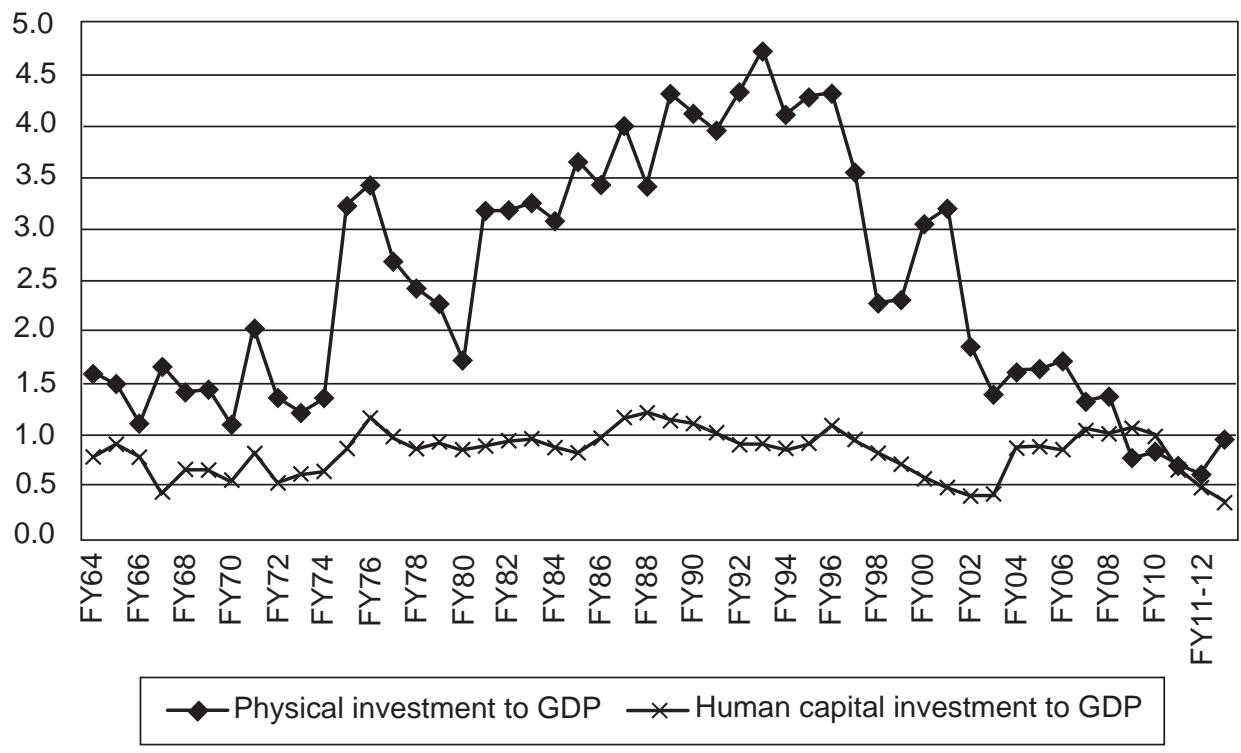

Source: Authors' own estimation based on the data series used for analysis.

the impact of these investments on sectoral and aggregate output growth. Notably, it has some unique features; the definition of human capital for the study as the sum of government health and education development expenditures has never been used before and the definition of physical capital as public investment in the electricity generation and distribution and gas generation and distribution sector plus public investment in the transport, storage and communication sector is also being used for the first time. Furthermore, no other study has examined the relative efficacy of public physical and human capital investment jointly, with exception of one conducted by Khan and Sasaki (2001). However, that study used different proxies for human and physical capital. This study also indicates which sector of the economy of Pakistan is benefiting the most from these investments. All and all, the study provides useful information for policymakers. The remaining section of the study is organized as follows: section II contains a review of past literature, section III provides an explanation of the methodological framework, section IV gives data and a diagnostic test, section $\mathrm{V}$ provides the basis for the empirical results and finally the conclusion and policy implications is discussed in section VI. 


\section{REVIEW OF LITERATURE}

The empirical literature related to the research for this study can be divided into three parts: (a) studies on the role of human capital in economic growth; (b) studies on the role of physical investment on economic growth: and (c) research work that explores the comparative effectiveness of physical and human capital.

Schultz (1961) stressed the importance of human capital as a major determinant of economic growth. Many studies that followed then examined the role of public investment in human capital in the form of health and education on the economic situation. A cross-country study by Maitra and Mukhopadhyay (2012) explored the impact of public health and education expenditures on economic growth through a vector autoregressive/vector error correction model (VAR/VECM) for 12 countries, namely Bangladesh, Fiji, Kiribati, Malaysia, Maldives, Nepal, the Philippines, the Republic of Korea, Singapore, Sri Lanka, Tonga and Vanuatu, based on annual time series data from 1981 to 2011 . The results of those studies showed that public education spending had a significant positive impact on economic growth in Bangladesh, Fiji, Kiribati, Maldives, Nepal, Singapore, Sri Lanka, Tonga and Vanuatu and a significant negative effect in Malaysia, the Philippines and the Republic of Korea. Meanwhile, health expenditures had a significant positive growth effect in Bangladesh, Nepal, the Philippines, Singapore and Sri Lanka, a significant negative growth effect in Kiribati, Malaysia, Maldives, the Republic of Korea and Vanuatu, and no effect in Fiji and Tonga.

Khan (2005) analysed the impact of human capital on economic growth by applying a cross-sectional regression for 72 low and middle-income countries, including Pakistan, and using the mean value of all selected variables for the period 1980-2002. Another variable used by Khan was average years of schooling, literacy rate, school enrolment and life expectancy at birth, as a proxy for human capital. The results show that the educational and health indicators have a significant positive effect on real per-capita growth. More specifically, in the case of Pakistan, Khan noted that even though human capital investment has been very low compared to other economies in Asia, it has had a significant effect on the country's economic growth rate, which can further be accelerated by increasing the quality of human capital. Tamang (2011) investigated the impact of education expenditures on GDP growth in India through Johansen cointegration on an annual data set covering the period 1980-2008. He found that a 1 per cent increase in public education expenditure per worker will lead to 0.11 per cent increase in GDP per worker. Ogungbenle, Olawumi and Obasuyi (2013) estimated the link among life expectancy, public health spending and economic growth in Nigeria using annual time series data for the period 1977-2008 through a VAR model and found a bi-directional causality between public 
health spending and economic growth. Hussin, Muhammad and Razak (2012) examined the impact of education expenditures on economic growth in Malaysia using a VECM model with the following variables: GDP; fixed capital formation; labour force participation; and public education expenditures. The results confirm that the education expenditures have Granger causality with GDP growth.

Akram, Padda and Khan (2008) investigated the impact of social capital on economic growth in Pakistan using an annual data series for the period 1972-2006 through a VECM model. The variables included per capita GDP, life expectancy, infant mortality, secondary school enrolment, population per bed and health expenditure as a percentage of GDP. The results show that the health indicators, except for health expenditures, have a significant impact on growth in the long run, but no significant impact in the short run. Abbas and Foreman-Peck (2007) estimated the impact of human capital on economic growth in Pakistan using data from 1960 to 2003 through the Johansen cointegration technique using the secondary enrolment to labour force ratio and health expenditure as a percentage of GDP as a proxy for human capital. They concluded that, among other factors, human capital had a high positive growth effect and that this growth effect was much greater in the case of health expenditure compared to education expenditure. Qadri and Waheed (2011) analysed the impact of human capital on economic growth in Pakistan by using a modified proxy, primary enrolment rate multiplied by expenditures on health as a percentage of GDP. For the study, time series data from 1978 to 2007 and the OLS technique were used. Qadri and Waheed (2011) found a highly significant positive growth effect of this health adjusted human capital.

The impact of physical capital formation through public spending on economic activities has been rigorously analysed in several studies. Pereira (2000) pioneered work in this area by investigating the effects of aggregate public investment and infrastructure investment at a disaggregated level by using a VAR model for the United States of America. He found that at both the aggregated and disaggregated levels, public investment had a positive effect on output and crowd in private investment. The study also showed that marginal productivity was 4.46, indicating that each dollar invested would increase private output by $\$ 4.46$, the highest rate of return was 16.1 per cent in the electric, gas, transit system and airfield sector.

Fan, Zhang and Zhang (2002) estimated the marginal productivity and returns of different public spending in research and development, irrigation, roads, education, electricity, and telephones in rural China using the panel data (1970-1997) of different provinces of China. The estimated results, based on a simultaneous equations model, indicated that investment in education has the highest marginal productivity among the types of public investment analysed. 
Wang (2005) analysed the impact of five different types of government expenditures in Canada: expenditure on protection of persons and property; capital and infrastructure; human capital; debt charges; and expenditure on government and social services on private investment. The study found a significant crowding-out effect of expenditure on capital and infrastructure while expenditure on human capital had a significant crowding-in effect. Murty and Soumya (2006) used a macroeconomic general equilibrium model to investigate the effect of public investment in infrastructure on growth and poverty from 1979 to 2003 in India. The results indicated that a 20 per cent sustained increase in public infrastructure investment finance through borrowing by commercial banks would increase real growth by 1.8 per cent and result in a 0.7 per cent decline in poverty. Pina and Aubyn (2006) examined the rate of return of public investment in the United States using a VAR model for the period 1956-2001. Four variables were used in the model, namely real private investment, real public investment, private employment and real private GDP. The results showed a positive partial-cost dynamic feedback rate of return of 7.33 per cent while the total or full-cost dynamic feedback rate of return was 3.68 per cent.

Marattin and Salotti (2014) estimated the multiplier effect of five different types of public spending on private consumption in the United Kingdom of Great Britain and Northern Ireland through a structural vector error correction (SVEC) model. They conclude that the shock in wages have a negative impact, while total public consumption and social security spending have a positive effect on private consumption. Ocran (2011) investigated the impact of government consumption expenditures, public investment, deficit and revenue on economic growth of South Africa using five different VAR models. The study was based on quarterly data from 1990 to 2004. The results suggest that government consumption expenditures, investment and tax revenue have a significant positive growth effect, with public consumption having the largest growth effect and the deficit having no significant impact on economic growth.

Saeed and Ali (2006) examined the effect of public investment at the aggregate and disaggregate levels in a VAR model using the following real variables: public investment; employed labour force; GDP; and private investment at the aggregate level and for the manufacturing and agriculture sectors. The study found that in agriculture, there was crowding in while in the manufacturing sector, the crowding out effect was prevalent and at the aggregate level, it was inconclusive. Naqvi (2003) analysed the impact of per worker aggregate public and private capital in Pakistan through a VECM model using data from the period 1965-2000. The findings were different under the assumptions of exogenous technological changes and endogenous technological changes. The time trend was used as a proxy of 
technological change in the model. The results showed that in the exogenous model, the elasticities of private and public capital per workers were 0.25 and 0.23 , respectively. In endogenous model the long-term elasticity of public investment is much higher at 0.49 and 0.29 , respectively.

Hyder (2001) examined the effect of real public investment on private investment and growth in Pakistan for the period 1964-2001 through a VEC model and found a complementary relationship between public and private investment and a positive growth effect. Khan and Sasaki (2001) analysed the impact of per worker public capital at the aggregated and disaggregated levels on economic growth in seven sectors, including agriculture for Pakistan. This study analysed the impact of public investment on aggregate private investment by using annual data series from 1964 to 1997 through a standard production function approach. The estimated elasticities of public investment at the aggregated and disaggregated levels, employment elasticity and private investment elasticities were positive, while the output elasticities to employment were negative in four of the seven sectors, namely in the energy, transport, communications and services sectors. Ammad and Ahmed (2014) analysed the impact of public energy sector investment on sectoral economic growth, private investment and employment in Pakistan. The estimation was based on VAR methodology covering the data period 1981-2011. They found a strong crowding-in effect of public energy investment, as the effects were positive in seven out of the eight sectors that were analysed, while, in terms of output, the public energy investment also has a positive effect in seven out of the eight sectors.

The existing literature specifically related to Pakistan revealed that different proxies have been used for human capital, such as secondary enrolment rate, health expenditures as percentage of GDP, life expectancy, infant mortality, and social welfare including community services and financial sector facilities. The physical capital stock is measured in terms of public investment in different sectors at the aggregate level, including the agriculture, manufacturing, energy, and transport and communication sectors.

\section{THEORETICAL FRAMEWORK AND ECONOMETRIC TECHNIQUE}

The objective of the present study is to determine the role of public physical and human capital investment in economic growth of Pakistan. To accomplish this, the production function approach based on Mankiw, Romer and Weil (1992) growth models is applied. It is formulated as follows:

$$
Y_{t i}=A_{t} K_{t i}^{\alpha} H_{t}^{\beta} L_{t i}^{1-\alpha-\beta}
$$


Where $Y$ is the output of ith sector, which is the function of capital investment in that sector $\left(\mathrm{K}_{\mathrm{ti}}\right)$, human capital $\left(\mathrm{H}_{\mathrm{t}}\right)$, and labour in that sector $\left(\mathrm{L}_{\mathrm{ti}}\right)$.

Capital investment is further broken up into general private investment, in a particular sector and public physical investment. Finally, an estimate is made of the following linear function after the log transformation of equation 1.

$$
\operatorname{LnY}_{\mathrm{ti}}=\mathrm{C}+\alpha \mathrm{LnK}_{\mathrm{ti}}+\gamma \mathrm{Ln} \mathrm{L}_{\mathrm{ti}}+\beta \mathrm{Ln} \mathrm{H}_{\mathrm{t}}+\delta \mathrm{Ln} \mathrm{Phy}_{\mathrm{t}}+\mu
$$

Where $\ln Y_{t i}$ is the log of real output in particular sector, $C=\ln A_{t}, Y=(1-\alpha-\beta)$, $\ln K_{t i}$ is the gross fixed capital formation by private sector in particular sector, $\ln L_{t i}$ is the log of employment in the particular sector, $\mathrm{InH}_{\mathrm{t}}$ is the log of real human capital, which is the sum of health and education development expenditures, InPhy $\mathrm{y}_{t}$ is the log of real physical capital investment, which comprises public investment in electricity generation, distribution and gas distribution sector plus public investment in transport, storage and communication sector. Theoretically, the expected signs of estimated coefficients are positive.

To test the long-run relationship between economic growth, public physical and human capital investment, the study employed FM-OLS introduced by Phillips and Hansen (1990). FM-OLS certainly has some significant advantages over other long-run estimation techniques, especially in case of a single cointegrating vector when all the data series are I(1). It also addresses the issues of serial correlation and endogeneity of the regressors; the problem of endogeneity arises when nonstationary series have cointegration links (Phillips, 1991; 1995). Furthermore, FM-OLS is a fully efficient estimation technique for a cointegrating regression even in the presence of different order of integration (Chang and Phillips, 1995). In order to ascertain the applicability of FM-OLS, the Breusch-Godfrey Serial Correlation LM Test was applied on each model, and the Johansen $(1991$; 1995) approach was used for a number of cointegrating vectors. The results of the Breusch-Godfrey Serial Correlation Lagrang Multiplier (LM) Test are shown in the annex table A.3, which indicates that the OLS estimation results have serial correlation in each of the model, while the cointegration results, mentioned in the annex table A.2 shows that there is only a single cointegrating vector, in each of the models. To incorporate these issues and have efficient long-run estimates, FM-OLS is applied, as discussed by Chang and Phillips (1995) and Phillips and Hansen (1990). 


\section{DATA SOURCE AND DESCRIPTION}

This study is based on annual time series data from 1964 to 2013 for three major sectors: agriculture, manufacturing, and services ${ }^{1}$ and the aggregate economy of the Pakistan. The data series are from the State Bank of Pakistan Annual Report, 50 Years of Pakistan Economy, and various issues of the Economic Survey of Pakistan, with the exception of the data on development expenditures on education, which are collected from poverty reduction strategy papers (PRSP) and from Social Policy and Development Centre (SPDC) Annual Review 2002-2003. The study converts all nominal variables into real by using the GDP deflator for 2005/06; the common base of 2005/06 deflator series is generated through the standard splicing technique. The different base year deflators' series of 1959/60, 1980/81, 1999/2000 and $2005 / 06$ are thereby combined. Finally, natural logarithm is applied to all variables used in this study.

\section{Univariate analysis}

In order to understand the order of integration of the variables and structural break points, if any, the Augmented Dickey-Fuller and Phillips Perron (PP) test is used to check the order of integration. The test results, which are given in the annex table A. 1 show that the variables are non-stationary at a level using a 5 per cent confidence interval, however, at a first difference, all the variables are stationary, in that they are I(I). Furthermore, the Schwarz (1978) and Akaike (1974) information criteria are applied for optimal lag length selection.

\section{Cointegration analysis}

To apply FM-OLS, it is fundamental that the variables must be cointegrated. For this, a cointegration test is applied to all models by using the Johansen (1991; 1995) approach. The test results, presented in the annex table A.2, show that, in the four models, there is at most one cointegration vector.

\section{Diagnostic test}

Two sets of diagnostic tests are applied to retrieve robust results through estimation, one on the long-run estimation results of FM-OLS and one on the shortrun estimation results of VECM. The lower part of table 1 shows that the values for $R^{2}$ and F-statistics of each model are highly significant. The presence of multicollinearity among exogenous variables is tested through the Coefficient Variance Decomposition

They consist on transport storage and communication, wholesale and retail trade, financial institutions banking and insurance, housing services and general government services. 
Table 1. Fully Modified Ordinary Least Square long-run elasticities

\begin{tabular}{|c|c|c|c|c|}
\hline \multirow{2}{*}{$\begin{array}{c}\text { Dependent } \\
\text { variable } \\
\stackrel{\longrightarrow}{\longrightarrow}\end{array}$} & Aggregate & $\begin{array}{c}\text { Manufacturing } \\
\text { sector }\end{array}$ & $\begin{array}{c}\text { Services } \\
\text { sector }\end{array}$ & $\begin{array}{c}\text { Agriculture } \\
\text { sector }\end{array}$ \\
\hline & $\begin{array}{l}\text { Aggregate } \\
\text { output }\end{array}$ & $\begin{array}{c}\text { Manufacturing } \\
\text { output }\end{array}$ & $\begin{array}{c}\text { Services } \\
\text { output }\end{array}$ & $\begin{array}{c}\text { Agriculture } \\
\text { output }\end{array}$ \\
\hline \multirow[t]{2}{*}{$\begin{array}{l}\text { Explanatory } \\
\text { variables }\end{array}$} & $\begin{array}{l}\text { Coefficient } \\
\text { (T-ratio) }\end{array}$ & $\begin{array}{l}\text { Coefficient } \\
\text { (T-ratio) }\end{array}$ & $\begin{array}{l}\text { Coefficient } \\
\text { (T-ratio) }\end{array}$ & $\begin{array}{c}\text { Coefficient } \\
\text { (T-ratio) }\end{array}$ \\
\hline & [Prob] & [Prob] & [Prob] & [Prob] \\
\hline \multirow[t]{3}{*}{ Private investment } & $0.19^{*}$ & $0.19^{*}$ & $0.096^{*}$ & $0.20^{*}$ \\
\hline & (15.93) & (11.90) & $(2.56)$ & (5.99) \\
\hline & {$[0.00]$} & {$[0.00]$} & {$[0.014]$} & {$[0.00]$} \\
\hline \multirow[t]{3}{*}{ Employment } & $1.58^{\star}$ & $0.48^{*}$ & $1.31^{*}$ & $1.281^{*}$ \\
\hline & (41.58) & $(10.81)$ & (15.93) & (8.67) \\
\hline & {$[0.00]$} & {$[0.00]$} & {$[0.00]$} & {$[0.00]$} \\
\hline \multirow[t]{2}{*}{$\begin{array}{l}\text { Public physical } \\
\text { investment }\end{array}$} & $\begin{array}{l}0.034^{*} \\
(5.24)\end{array}$ & $\begin{array}{l}0.084^{*} \\
(4.94)\end{array}$ & $\begin{array}{l}0.017 \\
(0.97)\end{array}$ & $\begin{array}{l}-0.015 \\
(-0.82)\end{array}$ \\
\hline & {$[0.00]$} & {$[0.00]$} & [0.34] & {$[0.41]$} \\
\hline \multirow[t]{2}{*}{$\begin{array}{l}\text { Public human } \\
\text { capital investment }\end{array}$} & $\begin{array}{l}0.027^{\star \star} \\
(2.22)\end{array}$ & $\begin{array}{c}0.44^{*} \\
(17.52)\end{array}$ & $\begin{array}{l}0.15^{\star} \\
(5.20)\end{array}$ & $\begin{array}{l}0.094^{*} \\
(2.72)\end{array}$ \\
\hline & [0.031] & {$[0.00]$} & {$[0.00]$} & {$[0.00]$} \\
\hline \multirow[t]{3}{*}{ Constant } & -4.48 & 1.49 & -0.67 & -1.66 \\
\hline & $(-19.77)$ & $(6.36)$ & $(-2.53)$ & $(-1.63)$ \\
\hline & {$[0.00]$} & {$[0.00]$} & {$[0.01]$} & {$[0.11]$} \\
\hline R-squared & 0.99 & 0.94 & 0.98 & 0.96 \\
\hline F-statistic & 2004.87 & 191.45 & 678.85 & 321.66 \\
\hline
\end{tabular}

Source: Authors' own estimation.

Notes: $\quad$ *, ${ }^{\star *}$ Indicates significance at $1 \%$ and $5 \%$, respectively.

test for each model; the results indicate no multicollinearity in each case. ${ }^{2}$ Finally, the residual of each model is saved and then the Box-Pierce/Ljung-Box Q-statistics is applied for a residual serial correlation test; the results imply that there is no serial correlation. Another set of diagnostic tests is applied to the vector error correction model (VECM); the results are displayed in the annex table A.5. The diagnostic results indicate that on the basis of the LM test, there is no serial correlation. The heteroskedasticity test shown in the annex table A.5; also confirms that there is no

2 For the sake of brevity the results are not reported, but are available on demand. 
heteroskedasticity. For parameters stability, the AR unit root test is applied ${ }^{3}$ which also confirms that all of the roots lie within the unit circle.

\section{EMPIRICAL RESULTS}

The estimated results, based on long-run elasticities are discussed in the annex table A.1, which is divided into five columns: the first column contains a list of explanatory variables and the remaining four columns represent each model. The results show that private investment has a significant positive effect on output in all four models, at the aggregate level and in the three sectoral models related to the manufacturing, services and agriculture sectors. The estimated coefficient indicates that the highest elasticity is in agriculture sector output ( 0.2 per cent), followed by manufacturing output ( 0.19 per cent), aggregate output ( 0.19 per cent) and services sector output ( 0.096 per cent) in the case of a 1 per cent change in private investment in the respective sector. In the case of employment, a 1 per cent change in respective employment brings the highest change in aggregate output (1.58 per cent) followed by services ( 1.31 per cent), agriculture (1.28 per cent) and manufacturing ( 0.48 per cent).

Physical investment has a positive significant effect on aggregate output and manufacturing output, while it is insignificant in the other two sectors. The coefficients of public physical investment indicates that a 1 per cent change in physical investment results in a 0.084 per cent change in manufacturing output, while in the case of aggregate output it results in a change of 0.034 per cent.

Public human capital has positive significant effect in the four models. The coefficient indicates that a 1 per cent change in human capital investment increases the output of the manufacturing sector by 0.44 per cent, output of the services sector by 0.15 per cent, output of the agriculture sector by 0.094 per cent and the aggregate output by 0.027 per cent. The estimated elasticities indicate that the largest benefit of human capital investment is in the manufacturing sector followed by the services and agriculture sectors. A comparison of the public human and physical capital investment shows that in the sectoral level, public human capital has a larger output effect than the public physical investment. However, at the aggregate level, public physical investment has a larger output effect than public human capital investment.

In addition to the long-run estimation, the VEC model is applied in each case to estimate the short-run dynamics through error correction term (ECT). The results, which are shown in the annex table A.3, indicate that, in all cases, the ECT coefficient

3 Results of the AR Unit root test are given in the annex. 
is significant with a theoretical negative sign. This significance also confirms the existence of cointegration. The coefficient of ECT is 29 per cent in the aggregate model, 49 per cent, in the manufacturing model, 54 per cent in the services model and 30 per cent in the agriculture model, for any deviation from equilibrium.

\section{SENSITIVITY ANALYSIS}

To test the robustness of the results, especially the sign and magnitude of the estimated elasticities, a sensitivity analysis is performed in which the models are re-estimated after reducing the sample size. The sensitivity results are shown in table 2, which depicts that all the parameters are stable in magnitude, sign and

Table 2. Fully Modified Least Squares long-run elasticities-sensitivity results

\begin{tabular}{|c|c|c|c|c|}
\hline \multirow[t]{2}{*}{$\begin{array}{c}\text { Dependent } \\
\text { variable }\end{array}$} & $\begin{array}{c}\text { Aggregate } \\
\text { model based on } \\
27 \text { observations }\end{array}$ & $\begin{array}{l}\text { Manufacturing } \\
\text { sector model } \\
\text { based on } 41 \\
\text { observations }\end{array}$ & $\begin{array}{l}\text { Services sector } \\
\text { model based on } \\
40 \text { observations }\end{array}$ & $\begin{array}{c}\text { Agriculture } \\
\text { sector } \\
\text { model based on } \\
36 \text { observations }\end{array}$ \\
\hline & $\begin{array}{l}\text { Aggregate } \\
\text { output }\end{array}$ & $\begin{array}{c}\text { Manufacturing } \\
\text { output }\end{array}$ & $\begin{array}{c}\text { Services } \\
\text { output }\end{array}$ & $\begin{array}{l}\text { Agriculture } \\
\text { output }\end{array}$ \\
\hline $\begin{array}{c}\text { Explanatory } \\
\text { variables }\end{array}$ & $\begin{array}{l}\text { Coefficient } \\
\text { (T-ratio) } \\
\text { [Prob] }\end{array}$ & $\begin{array}{l}\text { Coefficient } \\
\text { (T-ratio) } \\
\text { [Prob] }\end{array}$ & $\begin{array}{l}\text { Coefficient } \\
\text { (T-Ratio) } \\
\text { [Prob] }\end{array}$ & $\begin{array}{l}\text { Coefficient } \\
\text { (T-ratio) } \\
\text { [Prob] }\end{array}$ \\
\hline \multirow[t]{3}{*}{ Private investment } & 0.13 & 0.19 & 0.42 & 0.04 \\
\hline & $(4.76)$ & (3.21) & (13.74) & $(0.88)$ \\
\hline & {$[0.0001]$} & {$[0.0028]$} & {$[0.0000]$} & {$[0.3837]$} \\
\hline \multirow[t]{3}{*}{ Employment } & 0.7 & 0.92 & 0.76 & 2.4 \\
\hline & (3.92) & $(4.42)$ & (12.04) & (9.81) \\
\hline & {$[0.0007]$} & {$[0.0001]$} & {$[0.0000]$} & {$[0.0000]$} \\
\hline Public physical & 0.13 & 0.29 & 0.01 & -0.17 \\
\hline \multirow[t]{2}{*}{ investment } & (3.68) & (3.29) & $(0.96)$ & $(-4.57)$ \\
\hline & [0.0013] & [0.0022] & [0.3453] & {$[0.0001]$} \\
\hline Public human & 0.22 & 0.14 & 0.05 & 0.18 \\
\hline \multirow[t]{2}{*}{ capital investment } & $(4.24)$ & (1.1) & $(2.16)$ & (3) \\
\hline & {$[0.0003]$} & {$[0.2806]$} & [0.0379] & {$[0.0053]$} \\
\hline \multirow[t]{3}{*}{ Constant } & 2.21 & -1.42 & 1.64 & -9.91 \\
\hline & (1.76) & $(-1.21)$ & (6.65) & $(-5.69)$ \\
\hline & [0.0928] & [0.2324] & {$[0.0000]$} & {$[0.0000]$} \\
\hline
\end{tabular}


significance, with the exception of few deviations. In the agriculture sector, there is a minor deviation in the agriculture sector in which private investment has the same sign but is insignificant while physical investment becomes significant. In the manufacturing model, the sensitivity coefficient of human capital is insignificant, however, it has the same positive sign as in the main model.

\section{CONCLUSIONS AND POLICY IMPLICATIONS}

The present study provides some interesting new, which can help policymakers understand better the role of government policy in using public investment as a strategy to boost output in a country. The issue of development priorities is also addressed in this paper; the study results give empirical evidence that physical and human capital investments have a positive impact on the economy whereas human capital investment has more intense effects on output. The sectoral analysis further indicates that public human capital investment has a larger positive significant effect than the public physical investment on sectoral output in the three sectors covered in the study.

The results also support the growth stimulating impact of public investment. However, the Government of Pakistan and the International Monetary Fund have agreed to apply a strategy for economic growth through the private sector in which financing for that sector comes from the banking sector. They are of the view that this is possible after the fiscal deficit is reduced, and the government would need less money from the banking sector to meet its financing needs. This, in turn, would make more money available for the private sector. This strategy assumes that the economy has been facing a crowding-out phenomenon of public investment for private investment. However, in assuming a drastic reduction in the budget deficit, the downward rigidities of current expenditures and upward rigidity of revenue are not considered. In the Annual Review of SPDC (2001), an analysis shows that efforts to reduce the fiscal deficit cannot be achieved by cutting non-development expenditures or by increasing tax revenues. In most cases, governments have reduced budget deficits by cutting development expenditures, which then creates shortages in infrastructure and adversely affects private investment. Therefore, based on the experience of the Pakistan economy, proposed reductions in fiscal deficit will lead to the crowding-out effect. 


\section{REFERENCES}

Abbas, Qaisar, and James Foreman-Peck (2007). Human capital and economic growth: Pakistan 1960-2003. Cardiff Business School Working Papers Series, E2007/22. Cardiff, U.K.: Cardiff University.

Akaike, Hirotugu (1974). A new look at the statistical model identification. IEEE Transactions on Automatic Control, vol. 19, No. 6, pp. 716-723.

Akram, Naeem, Ihtsham UI Haq Padda, and Mohammad Khan (2008). The long term impact of health on economic growth in Pakistan. Pakistan Development Review, vol. 47, No. 4, pp. 487-500.

Ammad, Syed, and Qazi Masood Ahmed (2014). Dynamic effects of energy sector public investment on sectoral economic growth: experience from Pakistan economy. The Pakistan Development Review, vol. 53, No. 4, pp. 403-420.

Chang, Yooson, and Peter C.B. Phillips (1995). Time series regression with mixtures of integrated processes. Econometric Theory, vol. 11, No. 5, pp. 1033-1094.

Dickey, David A., and Wayne A. Fuller (1979). Distribution of the estimators for autoregressive time series with a unit root. Journal of the American Statistical Association, vol. 74, No. 3661, pp. 427-431.

Fan, Shenggen, Linxiu Zhang, and Xiaobo Zhang (2002). Growth, inequality, and poverty in rural China: the role of public investments. Research Report, No. 125. Washington, D.C.: International Food Policy Research Institute.

Hussin, Mohd Yahya Mohd, Fidlizan Muhammad, and Azila Abdul Razak (2012). Education expenditure and economic growth: a causal analysis for Malaysia. Journal of Economics and Sustainable Development, vol. 3, No. 7, pp. 71-81.

Hyder, Kalim (2001). Crowding-out hypothesis in a vector error correction framework: a case study of Pakistan. The Pakistan Development Review, vol. 40, No. 4 (part II), pp. 633-650.

Johansen, Soren (1991). Estimation and hypothesis testing of cointegrating vectors in Gaussian vector autoregressive models. Econometrica, vol. 59, No. 6, pp. 1551-1580.

(1995). Likelihood-based Inference in Cointegrated Vector Autoregressive Models. Oxford: Oxford University Press.

Khan, M. Tariq Yousuf, and Komei Sasaki (2001). Roles of public capital in Pakistan economy: productivity, investment and growth analysis. Review of Urban and Regional Development Studies, vol. 13, No. 2, pp. 143-162.

Khan, Mohsin S. (2005). Human capital and economic growth in Pakistan. The Pakistan Development Review, vol. 44, No. 4 (part I), pp. 455-478.

Lucas, Robert E., Jr. (1988). On the mechanics of economic development. Journal of Monetary Economics, vol. 22, pp. 3-42.

MacKinnon, James G., Alfred A. Haug, and Leo Michelis (1999). Numerical distribution functions of likelihood ratio tests for cointegration. Journal of Applied Econometrics, vol. 14, No. 5, pp. 563-577.

Maitra, Biswajit, and C.K. Mukhopadhyay (2012). Public spending on education, health care and economic growth in the selected countries of Asia and the Pacific. Asia-Pacific Development Journal, vol. 19, No. 2 (December), pp. 19-48.

Mankiw, N. Gregory, David Romer, and David N. Weil (1992). A contribution to the empirics of economic growth. The Quarterly Journal of Economics, vol. 107, No. 2, pp. 407-437. 
Marattin, Luigi, and Simone Salotti (2014). Consumption multipliers of different types of public spending: a structural vector error correction analysis for the UK. Empirical Economics, vol. 46, No. 4, pp. 1197-1220.

Murty, K.N., and A. Soumya (2006). Effects of public investment in infrastructure on growth and poverty in India. Working Papers, 2006-006. Mumbai, India: Indira Gandhi Institute of Development Research.

Naqvi, Naveed (2003). Is public capital more productive than private capital? Macroeconomic evidence from Pakistan, 1965-2000. Working Paper in Economics and Finance, No. 03/03. Durham, U.K.: University of Durham.

Ocran, Matthew Kofi (2011). Fiscal policy and economic growth in South Africa. Journal of Economic Studies, vol. 38, No. 5, pp. 604-618.

Ogungbenle, S., O.R. Olawumi, and F.O.T. Obasuyi (2013). Life expectancy, public health spending and economic growth in Nigeria: a vector autoregressive (VAR) model. European Scientific Journal, vol. 9, No. 19, pp. 210-235.

Pereira, Alfredo M. (2000). Is all public capital created equal? Review of Economics and Statistics, vol. 82, No. 3, pp. 513-518.

Phillips, Peter C.B. (1991). Optimal inference in cointegrated systems. Econometrica, vol. 59, Issue 2, pp. 238-306.

(1995). Fully modified least squares and sector autoregression. Econometrica, vol. 63, No. 5 (September), pp. 1023-1078.

Phillips, Peter C.B., and Bruce E. Hansen (1990). Statistical inference in instrumental variables regression with I(1) processes. The Review of Economics Studies, vol. 57, No. 1, pp. 99125.

Phillips, Peter C.B., and Pierre Perron (1988). Testing for a unit root in time series regression. Biometrika, vol. 75, pp. 335-346.

Pina, Alvaro M., and Miguel St. Aubyn (2006). How should we measure the return on public investment in a var? Economics Bulletin, vol. 8, No. 5, pp. 1-4.

Qadri, Faisal Sultan, and Abdul Waheed (2011). Human capital and economic growth: time series evidence from Pakistan. The Pakistan Business Review, vol. 1, pp. 815-833.

Romer, Paul M. (1990). Human capital and growth: theory and evidence. Carnegie-Rochester Conference Series on Public Policy. Elsevier, vol. 32, No. 1 (January), pp. 251-286.

Saeed, Norman, and others (2006). The impact of public investment on private investment: a disaggregated analysis. The Pakistan Development Review, vol. 45, No. 4, pp. 639-663.

Schultz, Theodore W. (1961). Investment in human capital. The American Economic Review, vol. 51, No. 1 (March), pp. 1-17.

Schwarz, Gideon. (1978). Estimating the dimension of a model. The Annals of Statistics, vol. 6, No. 2, (March) pp. 461-464.

Social Policy and Development Centre (SPDC) (2001). Social Development in Pakistan: Towards Poverty Reduction. Annual Review 2000. Oxford: Oxford University Press. Available from www.spdc.org.pk/Data/Publication/PDF/AR-3.pdf.

Tamang, Pravesh (2011). The impact of education expenditure on India's economic growth. Journal of International Academic Research, vol. 11, No. 3, pp. 14-20.

Wang, Baotai (2005). Effects of government expenditure on private investment: Canadian empirical evidence. Empirical Economics, vol. 30, No. 2, pp. 493-504. 


\section{ANNEX}

\section{Table A.1. Unit root analysis}

\begin{tabular}{|c|c|c|c|c|c|c|c|c|}
\hline \multirow{4}{*}{ Variables } & \multicolumn{4}{|c|}{ Augmented Dickey-Fuller test } & \multicolumn{4}{|c|}{ Phillips-Perron test } \\
\hline & \multicolumn{2}{|c|}{ Level } & \multicolumn{2}{|c|}{$1^{\text {st }}$ difference } & \multicolumn{2}{|c|}{ Level } & \multicolumn{2}{|c|}{$1^{\text {st }}$ difference } \\
\hline & $\begin{array}{c}\text { With } \\
\text { intercept }\end{array}$ & $\begin{array}{c}\text { With } \\
\text { trend and } \\
\text { intercept }\end{array}$ & $\begin{array}{c}\text { With } \\
\text { intercept }\end{array}$ & $\begin{array}{c}\text { With } \\
\text { trend and } \\
\text { intercept }\end{array}$ & $\begin{array}{c}\text { With } \\
\text { intercept }\end{array}$ & $\begin{array}{c}\text { With } \\
\text { trend and } \\
\text { intercept }\end{array}$ & $\begin{array}{c}\text { With } \\
\text { intercept }\end{array}$ & $\begin{array}{c}\text { With } \\
\text { trend and } \\
\text { intercept }\end{array}$ \\
\hline & p-value & p-value & p-value & p-value & p-value & p-value & p-value & p-value \\
\hline LAGG_GDP & 0.8996 & 0.3046 & $0^{*}$ & $0^{*}$ & 0.8422 & 0.2062 & $0^{*}$ & $0^{*}$ \\
\hline LMFG_GDP & 0.8209 & 0.4153 & $0^{*}$ & $0^{*}$ & 0.7144 & 0.2429 & $0^{*}$ & $0^{*}$ \\
\hline LSRV_GDP & 0.8069 & 0.3973 & $0^{*}$ & $0.0002^{*}$ & 0.6836 & 0.1027 & $0^{*}$ & $0^{*}$ \\
\hline LAGR_GDP & 0.9916 & 0.4334 & $0^{*}$ & $0^{*}$ & 0.9992 & 0.5576 & $0^{*}$ & $0^{*}$ \\
\hline LAGG_EMP & 0.993 & 0.535 & $0^{*}$ & $0^{*}$ & 0.993 & 0.4834 & $0^{*}$ & $0^{*}$ \\
\hline LAGR_EMP & 0.9715 & 0.1749 & $0^{*}$ & $0^{*}$ & 0.9951 & 0.1797 & $0^{*}$ & $0^{*}$ \\
\hline LMFG_EMP & 0.9441 & 0.7146 & $0^{*}$ & $0^{*}$ & 0.9441 & 0.6752 & $0^{*}$ & $0^{*}$ \\
\hline LSRV_EMP & 0.7515 & 0.1166 & $0^{*}$ & $0^{*}$ & 0.6234 & 0.1141 & $0^{*}$ & $0^{*}$ \\
\hline LAGG_IPRV & 0.9633 & 0.325 & $0^{*}$ & $0^{*}$ & 0.9591 & 0.3051 & $0^{*}$ & $0^{*}$ \\
\hline LAGR_IPRV & 0.9658 & 0.3391 & $0^{*}$ & $0^{*}$ & 0.9754 & 0.316 & $0^{*}$ & $0^{*}$ \\
\hline LMFG_IPRV & 0.8606 & 0.7351 & $0^{*}$ & $0.0004^{*}$ & 0.8403 & 0.6031 & $0^{*}$ & $0.0004^{*}$ \\
\hline LSRV_IPRV & 0.9589 & 0.3913 & $0^{*}$ & $0.0001^{*}$ & 0.9537 & 0.3481 & $0^{*}$ & $0.0001^{*}$ \\
\hline LHUMAN & 0.2072 & 0.3088 & $0.004^{*}$ & $0.0108^{*}$ & 0.48 & 0.508 & $0^{*}$ & $0^{*}$ \\
\hline LPHYSICAL & 0.0319 & 0.2817 & $0^{*}$ & $0.0001^{*}$ & 0.1695 & 0.8063 & $0^{*}$ & $0^{*}$ \\
\hline
\end{tabular}

Notes: $\quad{ }^{*},{ }^{* \star}$ and ${ }^{\star \star \star}$ show the stationarity at $1 \%, 5 \%$ and $10 \%$ level of significance, respectively.

LAGR is representing the log of agriculture sector, LMFG is the log of manufacturing sector, LSRV is the log of services sector, LAGG is the log of aggregate economy, GDP is the real output, EMP is the employment, IPRV is real private investment, LHUMAN is real human capital investment and LPHYSICAL is the real physical capital investment. 


\section{Cointegration test}

Table A.2. Johansen cointegration test

\begin{tabular}{|c|c|c|c|c|c|c|c|c|}
\hline Models & Hypotheses & $\begin{array}{c}\text { Trace- } \\
\text { test }\end{array}$ & $\begin{array}{c}5 \\
\text { per cent } \\
\text { critical } \\
\text { value }\end{array}$ & $\begin{array}{l}\text { Prob- } \\
\text { value }^{\star *}\end{array}$ & Hypotheses & $\begin{array}{l}\text { Max- } \\
\text { Eigen } \\
\text { Statistic }\end{array}$ & $\begin{array}{c}5 \\
\text { per cent } \\
\text { critical } \\
\text { value }\end{array}$ & $\begin{array}{l}\text { Prob- } \\
\text { value }\end{array}$ \\
\hline \multirow{5}{*}{$\begin{array}{l}\text { Aggregate } \\
\text { economy } \\
\text { model }\end{array}$} & $R=0^{*}$ & 97.05 & 88.80 & 0.01 & $R=0^{*}$ & 38.98 & 38.33 & 0.04 \\
\hline & $R \leq 1$ & 58.07 & 63.88 & 0.14 & $R \leq 1$ & 31.01 & 32.12 & 0.07 \\
\hline & $R \leq 2$ & 27.05 & 42.92 & 0.68 & $R \leq 2$ & 16.21 & 25.82 & 0.53 \\
\hline & $R \leq 3$ & 10.84 & 25.87 & 0.88 & $R \leq 3$ & 6.77 & 19.39 & 0.92 \\
\hline & $R \leq 4$ & 4.07 & 12.52 & 0.73 & $R \leq 4$ & 4.07 & 12.52 & 0.73 \\
\hline \multirow{5}{*}{$\begin{array}{l}\text { Agriculture } \\
\text { sector } \\
\text { model }\end{array}$} & $R=0^{*}$ & 96.62 & 88.80 & 0.01 & $R=0^{*}$ & 41.91 & 38.33 & 0.02 \\
\hline & $R \leq 1$ & 54.71 & 63.88 & 0.23 & $R \leq 1$ & 24.34 & 32.12 & 0.33 \\
\hline & $R \leq 2$ & 30.37 & 42.92 & 0.48 & $R \leq 2$ & 20.53 & 25.82 & 0.21 \\
\hline & $R \leq 3$ & 9.84 & 25.87 & 0.93 & $R \leq 3$ & 6.05 & 19.39 & 0.95 \\
\hline & $R \leq 4$ & 3.79 & 12.52 & 0.77 & $R \leq 4$ & 3.79 & 12.52 & 0.77 \\
\hline \multirow{5}{*}{$\begin{array}{l}\text { Manufacturing } \\
\text { sector model }\end{array}$} & $R=0^{*}$ & 99.43 & 88.80 & 0.01 & $R=0^{*}$ & 39.96 & 38.33 & 0.03 \\
\hline & $R \leq 1$ & 59.47 & 63.88 & 0.11 & $R \leq 1$ & 29.61 & 32.12 & 0.10 \\
\hline & $R \leq 2$ & 29.86 & 42.92 & 0.51 & $R \leq 2$ & 15.21 & 25.82 & 0.62 \\
\hline & $R \leq 3$ & 14.65 & 25.87 & 0.60 & $R \leq 3$ & 11.22 & 19.39 & 0.49 \\
\hline & $R \leq 4$ & 3.44 & 12.52 & 0.82 & $R \leq 4$ & 3.44 & 12.52 & 0.82 \\
\hline \multirow{5}{*}{$\begin{array}{l}\text { Services } \\
\text { sector } \\
\text { model }\end{array}$} & $R=0^{*}$ & 90.10 & 88.80 & 0.04 & $R=0^{*}$ & 41.51 & 38.33 & 0.02 \\
\hline & $R \leq 1$ & 48.59 & 63.88 & 0.48 & $R \leq 1$ & 20.06 & 32.12 & 0.65 \\
\hline & $R \leq 2$ & 28.52 & 42.92 & 0.59 & $R \leq 2$ & 13.42 & 25.82 & 0.77 \\
\hline & $R \leq 3$ & 15.10 & 25.87 & 0.57 & $R \leq 3$ & 9.27 & 19.39 & 0.70 \\
\hline & $R \leq 4$ & 5.83 & 12.52 & 0.48 & $R \leq 4$ & 5.83 & 12.52 & 0.48 \\
\hline
\end{tabular}

Notes: $\mathrm{R}$ indicates the number of cointegrating vectors.

* Denotes rejection of the null hypothesis at the 0.05 level.

** MacKinnon-Haug-Michelis (1999) p-values.

Table A.3. Pre-estimation test: Breusch-Godfrey Serial Correlation LM

\begin{tabular}{lc}
\hline Sectors/model & $\begin{array}{c}\text { Autocorrelation test } \\
\text { (p-value) }\end{array}$ \\
\hline Aggregate model & $0.0004^{\star}$ \\
Agriculture sector model & $0.0000^{\star}$ \\
Services sector model & $0.0005^{\star}$ \\
Manufacturing sector model & $0.0000^{\star}$ \\
\hline
\end{tabular}

Note: *Reject the null hypothesis of "No Serial Correlation". 


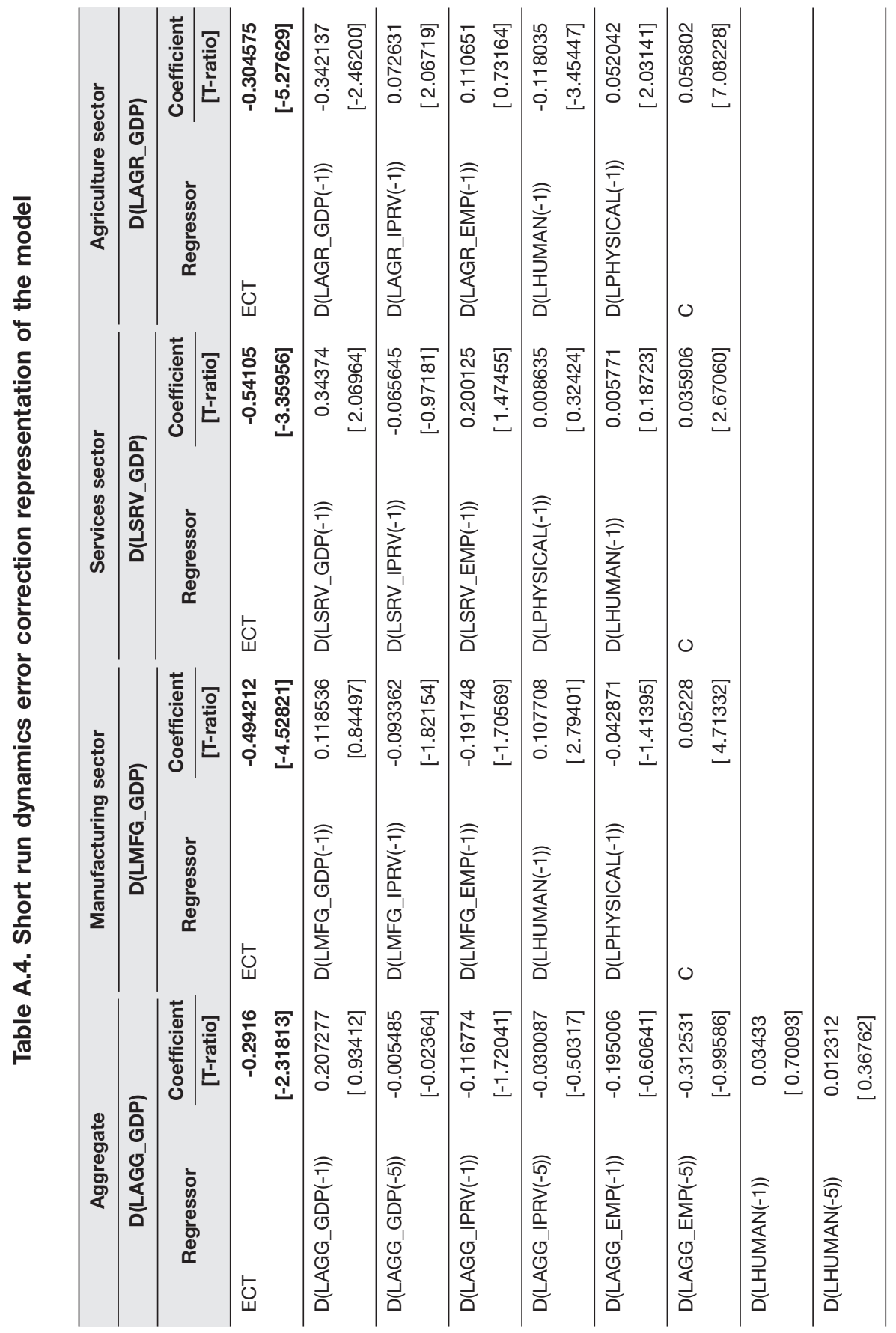




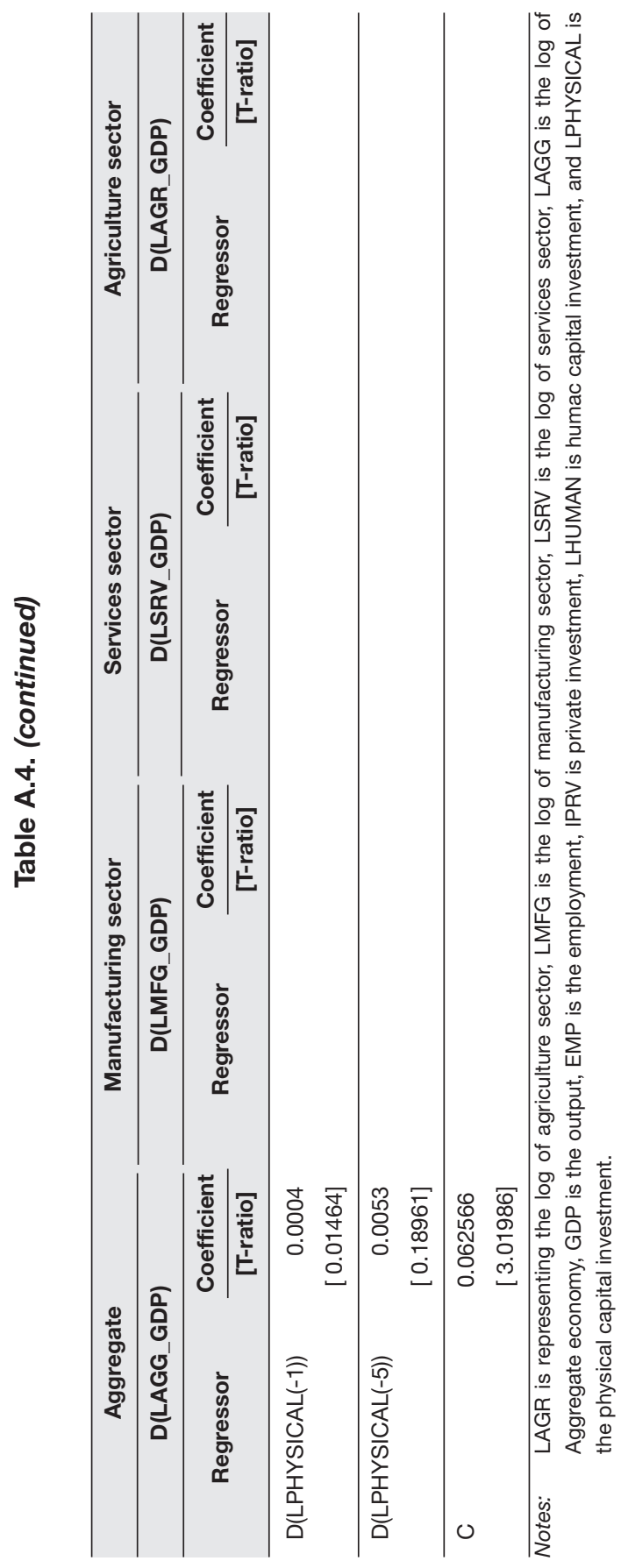


Table A.5. Post estimation diagnostic test

\begin{tabular}{lccc}
\hline Sectors/model & $\begin{array}{c}\text { Numbers of } \\
\text { lags }\end{array}$ & $\begin{array}{c}\text { Autocorrelation } \\
\text { test } \\
\text { (p-value) }\end{array}$ & $\begin{array}{c}\text { Heteroskedasticity } \\
\text { test } \\
\text { (p-value) }\end{array}$ \\
\hline Aggregate model & 1,5 & 0.5615 & 0.2187 \\
Agriculture sector model & 1 & 0.9936 & 0.629 \\
Services sector model & 1 & 0.6252 & 0.318 \\
Manufacturing sector model & 1 & 0.572 & 0.3154 \\
\hline
\end{tabular}

Notes: $\quad{ }^{1}$ Based on VAR residual serial correlation LM test with null no serial correlation.

${ }^{2}$ VAR Residual Heteroskedasticity Tests. For null hypothesis of no Heteroskedasticity.

Figure A.1. Parameters stability: AR root test

Aggregate model

Inverse roots of AR characteristic polynomial

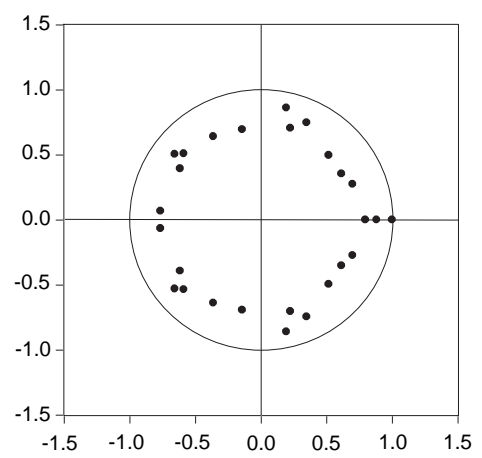

Agriculture sector

Inverse roots of AR characteristic polynomial

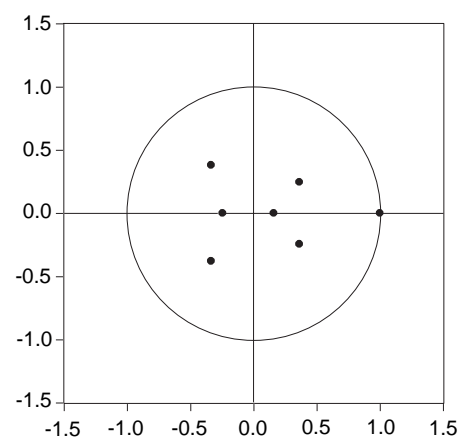

Manufacturing model

Inverse roots of AR characteristic polynomial

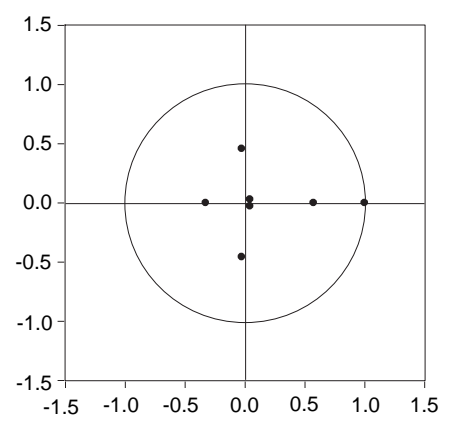

Services sector

Inverse roots of AR characteristic polynomial

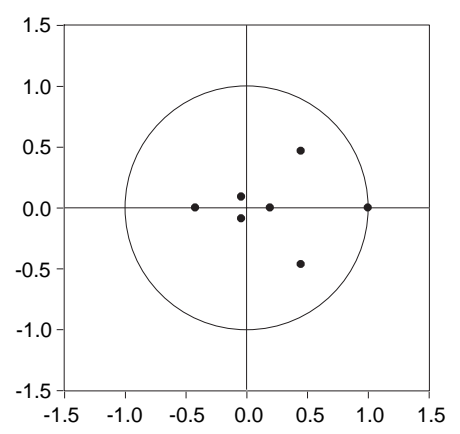

